
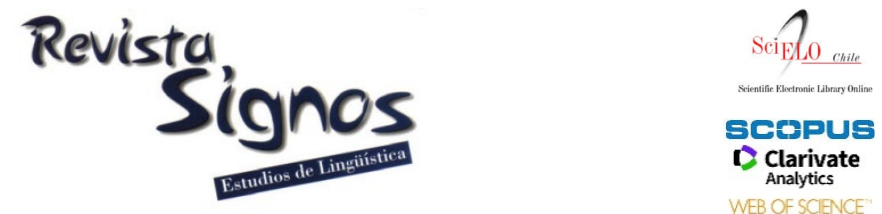

WEB OF SCIENCE

\title{
The effect of exposure to coherence relations on its processing and comprehension: Exploring Chilean primary school students' performance
}

\author{
El efecto de la exposición a relaciones de coberencia en su \\ procesamiento y comprensión: Una exploración al desempeño de \\ estudiantes chilenos de educación básica
}

Romualdo Ibáñez
Orellana
PONTIFICIA UNIVERSIDAD CATÓLICA DE
VALPARAíso
CHILE
romualdo.ibanez@pucv.cl

\author{
Fernando Moncada \\ Nahuelquín \\ UNIVERSIDAD DEL Bío Bío \\ CHILE \\ fmoncada@ubiobio.cl
}

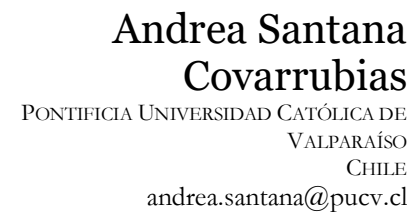

Andrea Santana Covarrubias VAIPARAÍsO CHILe andrea.santana@pucv.cl

Recibido: 21-VI-2021 / Aceptado: 10-XI-2021

DOI: $10.4067 /$ S0718-09342021000301026

\begin{abstract}
Previous corpus-based studies (Ibáñez, Moncada \& Cárcamo, 2019) have identified the most and the least frequent coherence relations in Chilean primary school textbooks. Based on these findings, in this study, we explored the effect of exposure to coherence relations on their processing and comprehension. We expected the most frequent coherence relations in school textbooks to be more easily processed and better comprehended than the least frequent ones. Our expectation is explained by integrating the Language Experience (LE) hypothesis (Nippold \& Taylor, 2002) and the Schematic Structural Expectations (SSE) hypothesis (Mulder, 2008). A self-paced reading experiment with a within-subjects design and cumulative window paradigm was carried out. One hundred and thirty-eight participants (12-14 years old), attending Chilean schools participated in the experiment. Each of them read 30 experimental items in two different sessions. Results revealed, in the first place, low levels of reading comprehension achievement. General results also showed that, although participants read the most frequent coherence relations slower than the least frequent ones, they comprehended them better. Analysis showed different patterns depending on the subject, which demonstrated that our expectations were partially fulfilled.
\end{abstract}

Key Words: Coherence relations, exposure, text structure, comprehension, processing. 


\section{Resumen}

Previos estudios basados en corpus (Ibáñez, Moncada \& Cárcamo, 2019) han identificado las relaciones de coherencia más y menos frecuentes en Textos Escolares chilenos. Basándonos en estos hallazgos, en este estudio, exploramos el efecto de la exposición a relaciones de coherencia en su procesamiento y comprensión. Se esperaba que las relaciones de coherencia más frecuentes en los Textos Escolares se procesaran más fácilmente y se comprendieran mejor que las menos frecuentes. Nuestra expectativa se explica al integrar las hipótesis Experience Language (LE) (Nippold \& Taylor, 2002) y Schematic Structural Expectations (SSE) (Mulder, 2008). Se llevó a cabo un experimento de lectura autoadministrada (self-paced reading task) con un diseño intra-sujeto y bajo el paradigma de ventana cumulativa. Ciento treinta y ocho participantes (de 12-14 años), que asistían a escuelas chilenas, participaron en el experimento. Cada uno de ellos leyó 30 ítems experimentales en dos sesiones diferentes. Los resultados revelaron, en primer lugar, bajos niveles de desempeño en comprensión. Los resultados generales también mostraron que, aunque los participantes leyeron las relaciones de coherencia más frecuentes más lentamente que las menos frecuentes, las comprendieron mejor. Los análisis mostraron patrones diferentes dependiendo de las asignaturas, lo que demostró que nuestras expectativas se cumplieron parcialmente.

Palabras Clave: Relaciones de coherencia, exposición, estructura textual, comprensión, procesamiento.

\section{INTRODUCTION}

Both strategy-based and memory-based models assume written discourse comprehension as a process in which a coherent mental representation of the discourse is constructed and then stored in episodic memory (van Dijk \& Kintsch 1983; Kintsch, 1998). This conception of the process involves the assumption that readers generate at least two levels of representation: the textbase, classically assumed as an interconnected net of propositions, linked by means of argument overlap (Kintsch \& van Dijk, 1978) and the situation model, understood as a coherent representation of the general situation described in the text (van Dijk \& Kintsch, 1983). Another common claim is that in order to generate a situation model, it is necessary to maintain coherence at a local and at a global level (Zwaan \& Singer, 2003; O’Brien \& Cook, 2015). This local coherence construction and its global integration requires readers to make use of their background knowledge to establish coherence relations (van Silfhout, Evers-Vermeul \& Sanders, 2015; Knoepke, Richter, Isberner, Naumann, Neeb, \& Weinert, 2017).

Not only because coherence relations (such as additive, causal, and contrastive relations) are represented at the level of the situation model (Mulder \& Sanders, 2012), but also because deep comprehension involves the construction of the latter (Kintsch, 1998), the role of coherence relations in communication and learning is central. Hence, a large body of research has been devoted to understanding coherence relations and varieties of related phenomena. Studies have concentrated on identifying different factors that affect their processing and comprehension. Some of them paying special 
attention to texts characteristics, such as connectives (van Silfhout, Evers-Vermeul \& Sanders, 2014; Kleijn, Pander Maat \& Sanders, 2019) and coherence relations internal complexity (Sanders, 2005; Evers-Vermeul \& Sanders, 2009), others focusing on individual differences, such as working memory capacity (Scholman, Demberg \& Sanders, 2020) and linguistic exposure (Zufferey \& Gygax, 2019, 2020). And also, hypotheses have been formulated in order to explain the differences observed in processing particular types of coherence relations (Sanders \& Noordman, 2000).

Among all these findings and proposals, there are two, which are of particular interest to the current study. First, the findings that relate the ability to understand connectives to the degree of language exposure (Zufferey \& Gygax, 2019, 2020). These findings go in line with the Language Experience (LE) hypothesis (Nippold \& Taylor, 2002), which assumes that those linguistic units that are more frequent in the language are learnt and understood better. Second, the Schematic Structural Expectations (SSE) hypothesis (Mulder, 2008), whose key idea is that readers' background knowledge about the structure of texts triggers schematic expectations that facilitate processing and comprehension of causal coherence relations.

In this study, we explore the effect of exposure to coherence relations on their processing and comprehension. To do so, we use the results of a previous study (Ibáñez et al., 2019), in which the most and the least frequent coherence relations in primary school textbooks of four different school subjects were identified. Results of that study also showed that while some relations are used across school subjects (Conjunction, Concept Description), others are used almost exclusively in certain school subjects (Condition-Event in Science, Basic Contrast in History, Deictic in Language, and Condition-Question in Mathematics).

The current study therefore connects the results of a previous corpus study with a discourse comprehension research question, by investigating whether the exposure to types of coherence relations affects their processing and comprehension. Besides, and unlike most existing research, in this work, exposure is not operationalized as formal instruction, but as the frequency of occurrence of the phenomenon under study (coherence relations) in school textbooks. Hence, we expect that coherence relations that are the most frequent in school textbooks will be more easily processed and comprehended than those that are less frequent. Our expectation can be explained by integrating the LE and the SSE hypotheses, assuming that exposure to a particular type of coherence relation will develop the necessary background knowledge about its structure to trigger schematic expectations, which may facilitate its processing and comprehension.

We conducted this study in honor of Giovanni, a generous colleague and friend, who devoted his academic life to the study of discourse comprehension and language in general. 


\section{Theoretical frame}

\subsection{Deep comprehension and previous knowledge}

Given the indisputable role that deep comprehension plays in educational settings (Britton, Stimson, Stennett \& Gülgöz, 1998; Parodi, Peronard \& Ibáñez, 2010; Parodi, de León, Julio, Burdiles, 2019; Wiley \& Myers, 2003; Kendeou, Rapp \& van den Broek, 2003; Ozuru, Dempsey \& McNamara, 2009; van Silfhout et al., 2015; Beker, Jolles \& van den Broek, 2017), a large body of research has been conducted over the last decades to identify its underlying processes and the extent to which they are modulated by individual and (con)textual factors (Goldman \& George, 2019; Magliano, Higgs \& Millis, 2019; O’Reilly, Sabatini \& Wang, 2019; Allen \& McNamara, 2020). As a result, it is currently accepted that deep comprehension involves both the construction of a situation model (Kintsch, 1998; Graesser, 2015; Beker et al., 2017; Kendeou \& O’Brien, 2018) and the execution of higher-order thinking skills such as the analysis, synthesis, and evaluation of information (Graesser, 2015; McNamara, Jacovina \& Allen, 2016). According to several current models of text comprehension, during the construction of the situation model, readers' existing knowledge is continually activated and integrated with textual information (Graesser \& Trabasso, 1994; van den Broek, Risden, Fletcher \& Thurlow, 1996; Kintsch, 1998; Kendeou \& O’Brien, 2016; Singer, van den Broek \& Kendeou, 2017). As a result, knowledge in readers' long-term memory is increased and refined. These modifications of knowledge are considered learning and become the prior knowledge that the reader brings to future reading activities (Afflerbach, 1986; Shapiro, 2004; Allen \& McNamara, 2020; Cervetti \& Wright, 2020).

A considerable number of empirical studies on the positive effects of knowledge in comprehension has been conducted over the last four decades. Across those studies, researchers have operationalized knowledge in different ways and have focused, consequently, on different aspects varying in the proximity of readers' knowledge to the specific text being comprehended in the study (see Cervetti \& Wright, 2020 for a review). Traditionally, among those studies, researchers have examined topic knowledge, defined as the knowledge that is closely related to the topic of the text used in the study (e.g., knowledge about the moon when reading a text about the moon) (McNamara, Kintsch, Songer \& Kintsch, 1996; Miller \& Keenan, 2009; Wolfe \& Woodwyk, 2010); domain knowledge, operationalized as knowledge that is connected to a disciplinary area but not necessarily related to the content of a particular text used in the study (e.g., knowledge about Astronomy when reading a text about the moon) (Britton et al., 1998; O’Reilly \& McNamara, 2007) and general world knowledge, typically defined as breadth of knowledge of school topics (science, language, history, etc.) (Best, Floyd \& McNamara, 2008; McNamara, Ozuru \& Floyd, 2011). Another major type of knowledge that has proven to play a pivotal role, particularly in educational settings, is the knowledge of text structures, which involves knowledge 
about the organization of ideas and the relationship among them (Armbruster, 2004: Shanahan, Callison, Carriere, Duke, Pearson, Schatschneider \& Torgesen, 2010).

\subsection{Knowledge of text structure}

One crucial idea that has influenced research on text comprehension is that readers understand a text more readily if they can use the writer's structure (displayed in the text) to create their own mental representation of the text (Meyer, 1975). Therefore, it is assumed that text structures not only describe the text itself but also depict readers' cognitive coherence representations (Meyer \& Freedle, 1984; Sanders \& Noordman, 2000; Bogaerds-Hazenberg, Evers-Vermeul \& van den Bergh, 2021). This idea goes in line with the assumptions claimed in current models of discourse comprehension, namely that the better the information is organized in mental schemata and elaborated with relevant prior knowledge, the more coherent the readers' situation model is (Kintsch, 1988, 1998). Consequently, one fundamental way to build a coherent mental representation is to use the global structure of the text (Anderson \& Pearson, 1984; Mann \& Thompson, 1986; Sanders, Spooren \& Noordman, 1992; Meyer \& Poon, 2001).

Due to limited processing capacity (Baddeley, 1992), readers cannot remember and learn all the information exposed in a text, so they must select some information for deeper encoding and further cycles of processing. To do so, readers can focus on the top levels of the structure of the text. Extensive research conducted in the last decades has shown that readers who use this strategy are likely to remember more of what they read and to recall more the most important information exposed in the text than those who do not use the strategy (Meyer, Brandt \& Bluth, 1980; Meyer, Young \& Barlett, 1989). It has also been found that proficient readers are more likely to attend to both the external organization of the text and the internal organization of ideas for a better understanding (Kendeou \& van den Broek, 2007; Meyer \& Rice, 1984). In addition, proficient readers' knowledge about genres and structures has a positive influence on their expectations and organization of the textual content while reading (Zwaan, 1994).

Accordingly, given the positive effects of recognizing the text structure during reading, several attempts have been made to improve text comprehension by providing explicit instruction about global text structure (for recent overviews of such interventions, see Ray \& Meyer, 2011; Pyle, Vásquez, Lignugaris/Kraft, Gilliam, Reutzel, Olszewski \& Pyle, 2017; Bogaerds-Hazenberg et al., 2021). Overall, results of these interventions have shown positive effects on comprehension and recalling from texts with typically achieving students, students at risk for reading difficulties, and students with learning disabilities (Armbruster, Anderson \& Ostertag, 1987; Weisberg, \& Balajthy, 1989; Dickson, Simmons \& Kame'enui, 1995; Shanahan et al., 2010; Meyer \& Ray, 2011; Duke, Pearson, Strachan \& Billman, 2011; Williams, Pollini, Nubla-Kung, Snyder, García, Ordynans \& Atkins, 2014). In consequence, knowledge of text 
structure, considered as one type of schematic knowledge (van Dijk \& Kintsch, 1983), is essential at school since it may lead students to pose relevant questions while reading and help them better anticipate, predict, and monitor their comprehension (Gersten, Fuchs, Williams \& Baker, 2001; Ogle \& Blachowicz, 2002). What is more, it is claimed that successful readers recognize text structures as a useful skill for improving their comprehension (Meyer \& Ray, 2011; Duke et al., 2011).

\subsection{Knowledge of local structures}

Knowledge of text structure also includes knowledge about how texts are structured at the local level, i.e., in terms of how adjacent discourse fragments are connected through coherence relations. After all, if a text is organized through causal structures at the global level (Meyer, 1975; Slater, 1985; Meyer \& Ray, 2011; Williams et al., 2014), it is logical to assume that its discourse fragments, or at least some of them, will be connected via causal relations to maintain the causal 'nature' of the text. This type of knowledge also plays a key role in discourse processing. According to the SSE hypothesis (Mulder, 2008), knowledge about text structure enables the reader to construct expectations about the text yet to come. This top-down hypothesis states that if readers have acquired knowledge about certain local structures (i.e., types of coherence relations), it should be the case that when they are processing the first part of the relation, the whole structure is triggered. For example, if readers have knowledge about Problem-solution relations or are familiar with them, reading the Problem part activates the whole structure in their knowledge leading them to expect that a Solution part is likely to be presented later in the text. Therefore, this activated structure functions as a framework against which the current representation of the text is built. Consequently, when the new textual information presented in the second part fits in with such expectations, it will be processed with greater ease. Previous studies have provided evidence for this hypothesis. Mulder (2008) found that when readers have strong expectations on the causal coherence relation that connects a previous segment to an upcoming one, they read the new information faster.

\subsection{Acquisition of knowledge of local structures}

One way to learn this knowledge is via explicit instruction about the structure of the relation. An alternate option, which is the idea behind the current study, is that language users can draw on their experience with how local structures are frequently used in texts. So, they can acquire this schematic knowledge through constant exposure to a given structure, particularly when it is highly frequent in the texts they read. This idea is based on the LE hypothesis (Nippold \& Taylor, 2002), which assumes that those units that are more frequent in the language are learnt and understood better.

Support for this hypothesis has been obtained in studies in which effects of both frequency and linguistic experience have been identified in different components and 
levels of language. For example, some studies demonstrate that readers are faster to understand both words (Solomon \& Howes, 1951; Rayner \& Raney, 1996; Gollan, Slattery, Goldenberg, Van Assche, Duyck \& Rayner, 2011) and structures (Tanenhaus \& Trueswell, 1995; MacDonald, 2013) that occur more frequently. It has also been found that familiarity (high frequency) of proverbs plays an important role in proverb comprehension for individuals of a wide age range (Nippold \& Haq, 1996). Similarly, children, adolescents, and adults find that more familiar idioms are easier to understand than less familiar ones (Levorato \& Cacciari, 1992; Nippold, Moran \& Schwarz, 2001; Nippold \& Taylor, 2002), while in other cases, adults outperform children in correctly recognizing familiar idioms. Results reported by Zufferey and Gygax $(2019,2020)$ seem to provide further evidence in support of this hypothesis. In their first study, they found that the high frequency of certain connectives in corpus influences the ability of adults to discriminate between correct and incorrect uses of those connectives. In their second study, they determined that frequency of connectives is a key factor in explaining teenagers' difficulties to correctly produce connectives bound to the written mode.

To sum up, these results suggest that the high frequency of certain linguistic elements belonging to different levels of language makes them familiar for language users and hence, more likely to be accessed during language processing. This familiarity influences reading comprehension given that it can lead the reader to create expectations, for example about the information yet to come (Schematic Structural Expectation hypothesis). In this context, the current study is the first to examine whether the high frequency of certain coherence relations in school textbooks influences the ease of their processing and comprehension in children.

\section{Method}

A self-paced reading experiment with a within-subjects design and with cumulative window paradigm was carried out to test whether there is an effect of exposure when participants read the second segment (S2) of a coherence relation. We expected the most frequent coherence relations to be more easily processed and better comprehended than the least frequent ones. Moreover, assuming that knowledge is transmitted differently depending on the context and, for that reason, coherence relations vary across school subjects (Ibáñez et al., 2019; Santana, Ibáñez, Moncada \& Zamora, 2021), we selected the most and the least frequent coherence relations used in three school subjects (i.e., History, Language and Science).

\subsection{Materials}

The exposure to coherence relations was operationalized in terms of the frequency of coherence relations in school textbooks. For this reason, we created 60 experimental items, 30 containing the most frequent relations and 30, the least frequent ones in three different school subjects (see Appendix A and B for all experimental items). Conjunctions (equivalent to List in RST) and Concept Description relations were 
identified as the most frequent relations in History, Language, and Science. ClaimArgument and Event Description relations were the least frequent coherence relations in History; Act-Purpose, and Claim-Argument in Language, and Condition-Event and Concept Specification in Science (Ibáñez et al., 2019). For definitions, formalizations and examples of each coherence relation considered in this study, see Appendix C.

Two more criteria were considered in the construction of these experimental items: genre and extension. As for the first one, only samples of the Content Exposition genre were selected, since it is the most frequent genre in Chilean school textbooks (Ibáñez, Moncada, Cornejo \& Arriaza, 2017). This is a pedagogical genre whose communicative purpose is to present key topics, specific to a subject matter. As for the second one, we ensured that the $\mathrm{S}_{2}$ of coherence relations had a similar length in words. Specifically, we considered means of 16 and 17 words for the $S_{2}$ of the most frequent and the least frequent coherence relations respectively.

No fillers were used in the present experiment because the total of experimental items alludes to varied topics in each school subject and contains different types of coherence relations. Therefore, the probability of spotting a pattern was low. The distribution of the total experimental items is presented in Table 1.

Table 1. Distributions of experimental items according to each type of coherence relations and school subject.

\begin{tabular}{|l|l|c|c|c|c|}
\hline \multicolumn{2}{|c|}{ Type of relation } & History & Language & Science & Total \\
\hline \multirow{2}{*}{ Most Frequent } & Conjunction & 5 & 5 & 5 & 15 \\
\cline { 2 - 6 } & Concept description & 5 & 5 & 5 & 15 \\
\hline \multirow{4}{*}{ Least frequent } & Claim-Argument & 5 & 5 & - & 10 \\
\cline { 2 - 6 } & Event Description & 5 & - & - & 5 \\
\cline { 2 - 6 } & Act-Purpose & - & 5 & - & 5 \\
\cline { 2 - 6 } & Condition-Event & - & - & 5 & 5 \\
\cline { 2 - 6 } & Concept Specification & - & - & 5 & 5 \\
\hline Total & & 20 & 20 & 20 & 60 \\
\hline
\end{tabular}

The total number of experimental items (60) was constructed by three students from the Master in Linguistics program at Pontificia Universidad Católica de Valparaíso (Chile), who received previous training in constructing materials for three months and were familiar with coherence relations. Then, items were revised by the authors of this paper, who discussed the differences until agreement was reached. Items were distributed in two lists, one containing texts with the most frequent coherence relations and the other with the least frequent ones. The order of presentation of these items was also randomized to prevent order effects. In this way, each participant read 30 experimental items in two different sessions. 


\subsection{Task}

Each experimental item was followed by a comprehension task, which consisted of selecting a sentence that best integrated the meaning of the coherence relation in each item. Three alternatives were presented. The design and elaboration of these alternatives involved different strategies. For the correct alternative, a sentence was constructed that captured the whole meaning of the relation and its type. For one of the incorrect alternatives, a sentence was constructed in which the propositional content was preserved, but the type of coherence relation was modified. For the other incorrect alternative, a sentence was constructed that contained only one segment of the relation $\left(\mathrm{S}_{1}\right.$ or $\left.\mathrm{S}_{2}\right)$. Moreover, the extension in terms of words of each alternative was carefully controlled to be similar. Thus, all alternatives had a maximum of 29 words. The selection and order of presentation of the incorrect alternatives in each experimental item were randomized to prevent order effects. Example (1) is a good illustration of how the experimental items were structured with their three corresponding alternatives:

(1) $S_{1}$ [En la obra teatral, el cierre del telón determina el término de un acto.] $S_{2}$ [En la actualidad es común que las obras dramáticas se estructuren en un solo acto.] (Language)

' $\mathrm{S}_{1}$ [In a play, the closing of the curtain determines the end of an act.] $\mathrm{S}_{2}$ [Nowadays, it is common for dramatic works to be structured in a single act.]'

a) El hecho de que los actos se cierren cuando baja el telón es la causa de la predominancia de obras de un solo acto en la actualidad.

'The fact that the acts close when the curtain comes down is the reason for the predominance of one-act plays today.'

b) En la actualidad es altamente frecuente que las obras dramáticas estén estructuradas en solo un acto.

'Nowadays, it is very common for dramatic works to be structured in only one act.'

c) Actualmente las obras dramáticas presentan un solo acto, cuyo término está determinado por el cierre del telón.

Nowadays, dramatic works present a single act, the end of which is determined by the closing of the curtain.'

Alternative a) is incorrect because whereas the propositional content is preserved (the closing of the curtains and the predominance of one-act plays nowadays), the type of the coherence relation was modified to a causal relation, which differs from the original one (conjunction). Alternative b) is also incorrect because the sentence contains only one part of the coherence relation $\left(\mathrm{S}_{2}\right)$ (nowadays, most of the dramatic works are structured in only one act). Finally, alternative c) is the correct one because the sentence maintains both the propositional content and the type of coherence relation, i.e., a Conjunction, where the two connected events share only a common topic (acts in dramatic works). 


\subsection{Participants}

One hundred and thirty-seven students (11-14 years old) participated in this selfpaced reading experiment. All of them are native speakers of Spanish and typically developing children. Written informed consent was obtained from the parents of all participants and written informed assent was obtained from all participants. Both documents described the specific task that participants had to do.

\subsection{Procedure}

The experiment was executed with the free cross-platform PsychoPy (v2.0 ${ }^{1}$ in two sessions (one for each list). The same procedure was implemented in both sessions. First, participants were asked to provide information regarding their names, age, grade, school, and gender. Then, they were located in front of a personal laptop, read general instructions, and accepted a consent form. Next, they were presented with the experimental platform, which contained specific instructions. Specifically, participants were asked to read comprehensively 30 short texts. They were informed that after each text, three sentences would appear, and they had to select the sentence that encompasses the central meaning of the text presented previously. Participants were also warned that all sentences were related to the information of the previous text in terms of meaning, but just one encompasses the central meaning completely. Additionally, they were asked to select one of these alternatives, by pressing one out of three different keys on the keyboard. Furthermore, participants had to press the spacebar of the laptop to advance in the experiment. In this way, they read at their own pace. Participants underwent a practice trial before the experimental trials to learn the task. Finally, there was room for questions, and once these were resolved, participants started the experiment.

By considering example (1), the presentation order was as follows: First, $\mathrm{S}_{1}$ was presented on the screen (see Figure 1). Then, by pressing the spacebar, $S_{2}$ was presented next to $S_{1}$. Consequently, both segments could be seen on the screen. Next, by pressing the spacebar, both segments disappeared, and the comprehension task was displayed on the screen. Every time that participants pressed the spacebar, reading times were registered in seconds. We expected to find an effect of the exposure when participants had to read $S_{2}$. Specifically, it was expected that the processing of $S_{2}$ was faster by reading a frequent coherence relation than by reading a least frequent coherence relation. 


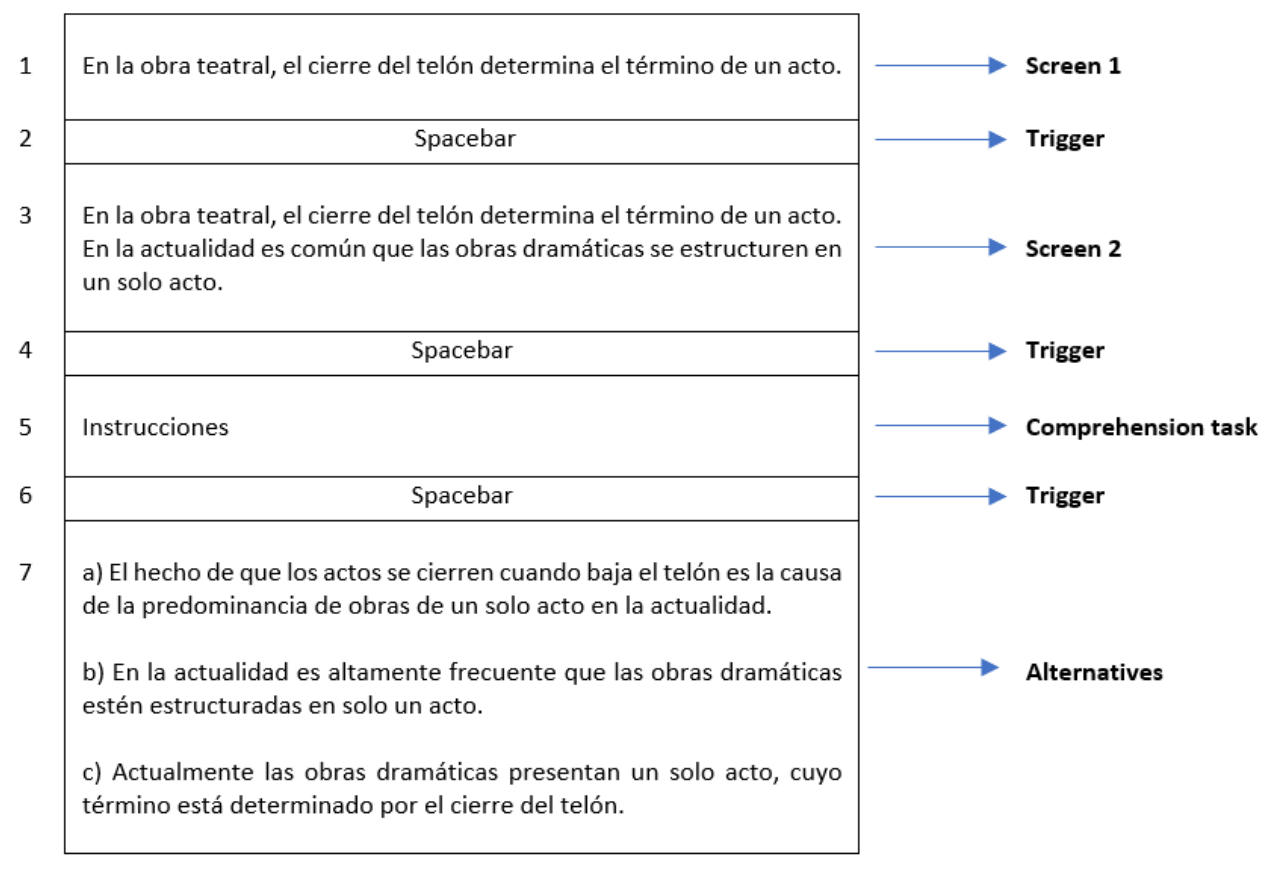

Figure 1. Experimental sequence.

\subsection{Statistical analysis}

Data related to the reading times of $S_{2}$ and the accuracy of responses in each item were considered to explore the effect of exposure on coherence relations processing and comprehending, respectively. Specifically, the Anderson-Darling normality test was carried out to identify the data distribution. Given that the data did not follow a normal distribution, the Kruskal-Wallis test was used to assess the difference between the means across conditions (the most and the least frequent coherence relation). Analyses were performed using $\mathrm{R}$ ( $\mathrm{R}$ Core Team 2018, version 4.0.3).

\section{Results}

Prior to the analyses, data of 23 participants were removed because their general and per school subject processing time exceeded the maximum value in data $(>24.62 \mathrm{~s}$. in general performance, $>29.32$ s. in History, $>28.90$ s. in Language, and 21.65 s. in Science). The following results are based on a total of 228 observations, corresponding to the answers of 114 participants. The results obtained in general performance and performance per school subject are provided in the sections that follow.

\subsection{General performance}

Table 2 shows means and standard deviations regarding correct responses and reading times per type of relation. 
Table 2. Means and standard deviations regarding the total of correct responses and reading times of $S_{2}$ in seconds.

\begin{tabular}{lcccc}
\hline General performance & \multicolumn{2}{c}{ Most frequent relations } & \multicolumn{2}{c}{ Least frequent relations } \\
\hline & $\overline{\mathrm{X}}$ & $\mathrm{SD}$ & $\overline{\mathrm{X}}$ & $\mathrm{SD}$ \\
\hline Correct responses & 17.83 & 5.33 & 15.88 & 4.62 \\
Reading times & 12.18 & 4.82 & 9.73 & 3.50 \\
\hline
\end{tabular}

The Kruskal-Wallis test shows a statistically significant difference between the means of correct responses of the most and the least frequent coherence relations $(\mathrm{H}=7.28$, $\mathrm{df}=1, p$-value $=0.006$ ). Results also reveal a statistically significant difference between the means of reading times achieved in the most and the least frequent coherence relations $(\mathrm{H}=14.74, \mathrm{df}=1, \mathrm{p}$-value $=0.0001)$.

\subsection{Performance per school subject}

This section describes the results obtained in each school subject separately.

\subsubsection{History}

Table 3 presents means and standard deviations regarding correct responses and reading times per type of relation in History.

Table 3. Means and standard deviations regarding the total of correct responses and reading times of $S_{2}$ in seconds.

\begin{tabular}{lcccc}
\hline History & \multicolumn{2}{c}{ Most frequent relations } & \multicolumn{2}{c}{ Least frequent relations } \\
\hline & $\overline{\mathrm{X}}$ & $\mathrm{SD}$ & $\overline{\mathrm{X}}$ & $\mathrm{SD}$ \\
\hline Correct responses & 6.09 & 2.21 & 4.26 & 1.76 \\
Reading times & 13.54 & 5.61 & 11.44 & 4.42 \\
\hline
\end{tabular}

Statistically significant difference was identified between the means of correct responses of the most and the least frequent coherence relations $(\mathrm{H}=38.02, \mathrm{df}=1, p$ value $=6.992 \mathrm{e}-10)$. Additionally, results reveal a statistically significant difference between the means of reading times achieved in the most and the least frequent coherence relations in this school subject $(\mathrm{H}=8.07, \mathrm{df}=1, p$-value $=0.004)$.

\subsubsection{Language}

Data in Table 4 correspond to means and standard deviations regarding correct responses and reading times per type of relation in Language. 
Table 4. Means and standard deviations regarding the total of correct responses and reading times of $S_{2}$ in seconds.

\begin{tabular}{lcccc}
\hline Language & \multicolumn{2}{c}{ Most frequent relations } & \multicolumn{2}{c}{ Least frequent relations } \\
\hline & $\overline{\mathbf{X}}$ & $\mathrm{SD}$ & $\overline{\mathrm{X}}$ & $\mathrm{SD}$ \\
\hline Correct responses & 5.39 & 1.82 & 5.06 & 2.26 \\
Reading times & 12.44 & 5.65 & 10.56 & 4.87 \\
\hline
\end{tabular}

The Kruskal-Wallis test demonstrates that there was no statistically significant difference between the means of correct responses of the most and the least frequent coherence relations $(\mathrm{H}=1.15, \mathrm{df}=1, p$-value $=0.28)$. On the contrary, results reveal a statistically significant difference between the means of reading times achieved in the most and the least frequent coherence relations $(\mathrm{H}=7.21$, $\mathrm{df}=1, p$-value $=0.007)$.

\subsubsection{Science}

Table 5 provides means and standard deviations regarding correct responses and reading times per type of relation in Science.

Table 5. Means and standard deviations regarding the total of correct responses and reading times of $S_{2}$ in seconds.

\begin{tabular}{lcccc}
\hline Science & \multicolumn{2}{c}{ Most frequent relations } & \multicolumn{2}{c}{ Least frequent relations } \\
\hline & $\overline{\mathrm{X}}$ & $\mathrm{SD}$ & $\overline{\mathrm{X}}$ & $\mathrm{SD}$ \\
\hline Correct responses & 6.35 & 2.53 & 6.55 & 2.01 \\
Reading times & 10.56 & 4.13 & 7.20 & 2.66 \\
\hline
\end{tabular}

The same as in Language, there was no statistically significant difference between the means of correct responses of the most and the least frequent coherence relations $(\mathrm{H}=.17, \mathrm{df}=1, p$-value $=0.67)$. Contrastingly, results reveal a statistically significant difference between the means of reading times achieved in the most and the least frequent coherence relations $(\mathrm{H}=44.01, \mathrm{df}=1, p$-value $=3.256 \mathrm{e}-11)$.

\section{Discussion}

\subsection{General performance}

Before discussing the results students obtained when processing the most and least frequent coherence relations, their overall performance will be briefly addressed. As exposed in the previous section (see Table 1), out of 30 possible points, students scored 17.83 on average in the most frequent condition and only 15.88 in the least frequent one. Taken altogether, this implies that out of 60 points, they scored 33.71 on average (56\% of success). 
These results are consistent with the ones reported not only in national (SIMCE, 2016) and international standardized tests (PISA, 2014) but also in other recent studies conducted with Chilean students. For example, in one of the experiments reported by García, Bustos and Sánchez (2015), they found that sixth-grade students (11-12 years old) had a low level of performance not only when answering literal and inferential open-questions but also on the variables examined in the study (knowledge about anaphors, organizational signals and refutations) (below $50 \%$ of success). Similarly, in a study in which 2 nd to 8 th grade students were asked to answer multiple choice tests measuring different aspects of literal, inferential and critical levels, Gallego, Figueroa and Rodríguez (2019) found a general poor performance in all measures. In another study, Pezoa and Orellana (2021) reported that more than half of fifth-year students (10-11 years old) obtained low levels of comprehension when answering a standardized test (Dialect ${ }^{2}$ ). In yet another study, Figueroa and Tobías (2018) asked students questions aimed at the literal, inferential and critical levels and found that fourth graders (9-10 years old) obtained low scores. Indeed, their performance is below expected according to the national curriculum. Finally, Ibáñez, Moncada and Cárcamo (in press), when exploring the influence of subjectivity and of connectives on reading comprehension and processing of fragments extracted from school textbooks, asked eighth graders to answer multiple-choice questions. Results indicate that, on average, students show low levels of reading comprehension (below $50 \%$ of success). In that study, it was also determined that shorter reading times did not result in a better comprehension, which could have been due to students' low reading proficiency.

Collectively, given the critical role reading comprehension plays in educational settings, these results suggest that Chilean children and adolescents encounter major difficulties when reading to learn. In addition, given their underperformance in different reading comprehension measures, most Chilean students, and particularly those who participated in this experiment, can be regarded as low-skilled readers. It is worth highlighting that in this study texts were extracted from the actual school textbooks they must study and hence, they dealt with familiar topics for the students. Therefore, our results seem to indicate that students' low levels of achievement could be due to their poor reading skills rather than to their lack of previous knowledge about the topics.

\subsection{General differences}

Results obtained when processing the most and least frequent coherence relations indicate that, although participants read the most frequent coherence relations slower than the least frequent ones, they comprehended them better. This difference, then, suggests that exposure might be a factor in explaining students' performance when establishing coherence relations and, therefore, comprehending the texts used to communicate relevant contents in their school textbooks. These results are consistent with the findings from other studies in which exposure has been similarly 
conceptualized. Some of these studies have proved that adults with less exposure to language have difficulties recognizing correct and incorrect uses of connectives (Zufferey \& Gygax, 2019); also, that teenagers with more exposure to language master the meaning of connectives better than those with less exposure to language (Zufferey \& Gygax, 2020); and, that language exposure affects language comprehension at the discourse level (Arnold, Strangmann, Hwang, Zerkle \& Nappa, 2018). Along the same line of thought, our general results may indicate that, as participants had a greater exposure to Conjunction and Concept Description coherence relations, they were able to successfully access their schematic structure to elicit expectations. Hence, we assume that after reading the first discourse segment, participants expected a second event that they could link to the first one in two possible patterns, either by topic or contextual similarity (Conjunction), or by the complementation of information to a concept in the first event (Concept Description). Example (2) corresponds to a Conjunction coherence relation.

(2) $S_{1}$ [Por las mañanas, en la costa, se forma una neblina espesa llamada Camanchaca.] $\mathrm{S}_{2}$ [En el altiplano, durante el verano, se producen fuertes lluvias y tormentas conocidas como invierno altiplánico.]

' $\mathrm{S}_{1}$ [In the mornings, on the shore, there is a thick fog called Camanchaca.] $\mathrm{S}_{2}$ [In the Andean Highlands, in the summer, there are heavy rains and storms known as Andean Highlands winter.]'

In the case of the example (2), the Conjunction relation can be established by linking the event presented in $S_{1}$ and the event presented in $S_{2}$ by means of topic similarity: geography and climate. This is the pattern that most coherence relations follow in Chilean school textbooks (Ibáñez et al., 2019). Hence, after reading about climate on the shore, introduced by prepositional phrases with temporal and special adverbial functions in $S_{1}$, the reader will not expect an argument or a consequence in $S_{2}$, but more information regarding climate and geography, which fit in with the prepositional phrases with temporal and special adverbial functions in $S_{2}$.

Based on what we have exposed so far, our data seem to support the integration of the LE hypothesis (Nippold \& Taylor, 2002) and the SSE hypothesis (Mulder, 2008). Nonetheless, there was no apparent relation between comprehension and processing performance, given that while the least frequent coherence relations were processed faster, the most frequent ones were comprehended better. A possible explanation for this unexpected pattern can be found in the general performance of students, who can be regarded as low-skilled readers. Similar results in Chile (Ibáñez et al., in press) and in other countries (van Silfhout, Evers Vermeul \& Sanders, 2015; Kleijn, 2018) have shown that less skilled readers struggle with the necessary integrative and inferential processes required to construct a coherent representation. Hence, it could be the case that unfamiliarity with the least frequent coherence relations made low reading skills students simply skip some of them. This phenomenon would explain speed and achievement. On the other hand, due to exposure to Conjunction and Concept 
description coherence relations, students were familiar enough to trigger schematic expectations that allowed them to comprehend the most frequent coherence relations better than the least frequent ones. In this same line of thought, we understand that processing speed is a predictor of comprehension; however, whereas slow processing speed is most of the times assumed as a predictor of difficulty in comprehension, it can also be the case that high speed correlates with low performance (Teasdale, 2020). In the case of the current study and taking into consideration that the most frequent coherence relations were better comprehended than the least frequent ones, we could also infer that fast reading correlates with low comprehension.

Results of previous studies have shown that characteristics of coherence relations also play a role in participants' processing performances (Traxler, Bybee \& Pickering, 1997; Traxler, Sanford, Aked \& Moxey, 1997; Sanders \& Noordman, 2000). Therefore, besides pointing at the reading skills of participants as the only reason for the unexpected pattern that we found in processing, we explored a complementary explanation in the internal characteristics of the coherence relations under study. To do so and given that the least frequent coherence relations considered in the current study vary in History, Language and Science (see Table 1), we carried out a per-school subject analysis.

\subsection{Differences by School Subject}

In the case of History, they are in line with those obtained in general performance (i.e., least frequent coherence relations were read faster, but most frequent ones were better comprehended). The processing inconsistency we found in our general results led us to think that besides low reading skills, an alternative explanation could be explored by relating the SSE hypothesis and the internal structure of coherence relations. The idea in this top-down hypothesis is that there are types of coherence relations whose internal configuration offers more salient features than others to trigger schematic expectations given that their configurations are more specific. In the case of History (leaving both additive coherence relations aside, Concept Description and Event Description), the type of coherence relation identified as least frequent (ClaimArgument) has more salient features (hedges, boosters, appraisal phrases, etc.) than the most frequent (Conjunction), so it is expected to trigger more expectations. Consequently, identifying the Claim part would trigger the whole Claim-Argument structure. That is, reading the claim part would activate the Claim-Argument structure in the knowledge of the reader and would, subsequently, facilitate processing. So, an alternative explanation for our results would be that the effect of salient features was stronger than exposure during integration. However, shorter times in processing did not result in more comprehension.

We could claim, then, that given the familiarity with Conjunctions and Concept Descriptions, participants overcame the potential difficulties imposed by the internal 
structure of Conjunctions during processing and were able to comprehend the most frequent coherence relations better. Hence, regardless of processing speed, results in History also suggest that exposure is a factor in explaining students' performance. The same as in our general results, it seems that greater exposure to Conjunction and Concept Description coherence relations allowed the necessary familiarity for students to access their schematic structure and elicit expectations that would scaffold comprehension.

In Language, results were not in line with our expectations neither in comprehension nor in processing measures. In the case of reading comprehension, no differences were found in the scores obtained across conditions, while in processing, results show that the least frequent relations were read faster than the most frequent ones. Similar to previous studies with Chilean students (Moncada, 2018; Ibáñez et al., in press), in which reading times and scores in reading comprehension tasks were collected, we found that faster reading times do not necessarily result in a high-quality comprehension. Consequently, these results provide further evidence to claim that faster reading times do not necessarily result in the construction of a solid mental representation.

As we have been arguing so far, the shorter reading times of the least frequent relations could be due to their internal nature (Act-Purpose and Action-Reason). Both relations are causal and volitional since the segments are connected through an implication relation, in the first place, and they both involve goal-oriented actions (Sanders et al., 1992; Ibáñez, Moncada \& Santana, 2015; Ibáñez et al., 2019). While in Act-Purpose, $S_{1}$ presents an action carried out to achieve a goal specified in $S_{2}$, in Action-Reason, $\mathrm{S}_{1}$ presents an action whose motivation is exposed in $\mathrm{S}_{2}$ (see Appendix A). The SSE hypothesis predicts that causal relations, such as these ones, trigger higher or more expectations than non-causal relations (such as Conjunction and Concept description), which if fit in, reduces the cognitive load involved and speeds up the processing of the new information. In consequence, it could be claimed that when students read the Act part of the relation, they activate their schematic knowledge about the relation and expect to find next either the reason why such action was developed or the goal it pursued. In addition, given that the Reason or Purpose part of the relation is explicitly introduced by the connective expressions ya que ('since') or porque ('because') and para + infinitivo ('to + infinitive') respectively (Santana et al., 2021), expectations about the information to come are fit in from the very beginning of $\mathrm{S}_{2}$. Therefore, the cognitive load is reduced, and the integration of both segments seems to be facilitated, which in turn, leads to shorter reading times, as observed in our data.

These results suggest that when reading the $S_{1}$ of these causal relations students expected to find certain type of information in $S_{2}$, but even when those expectations were fulfilled, they did not fully understand the content. In addition, it seems that the high frequency of the relations studied in this subject does not facilitate students' comprehension. Therefore, our data do not support evidence for the integration of the 
SSE hypothesis and the LE hypothesis. Rather, they seem to suggest that the schematic knowledge about the type of relation can be triggered due to its internal nature regardless of its frequency. Thus, our data seem to suggest that the differences in the processing patterns can be explained only by the SSE hypothesis (Mulder, 2008). However, this should be taken cautiously given the low scores obtained in the comprehension task.

In Science, results did not support our expectations either. They were very similar to those found in Language. The most frequent relations were not comprehended better nor processed faster than the least frequent ones. These findings, again, confirm that the subjects' performance is low when facing those coherence relations occurring frequently in their school texts, which certainly can be detrimental to their learning process.

Assuming that the internal structure of the least frequent coherence relations might be an alternative explanation for the processing inconsistency identified, let us now turn to these relations used in Science items. One of them was Condition-Event, which is a causal relation. The segments of this type of relation not only share a common contextual situation -which is the case of Conjunctions (one of the frequent relations)but also keep an implicational relation (Ibáñez et al., 2015). Furthermore, in ConditionEvent relations, the content of $S_{1}$ presents a condition for the (non)occurrence of another event that is presented in $S_{2}$ and it is almost always explicit (Hoek, Zufferey, Evers-Vermeul \& Sanders, 2017), that is to say that they are introduced by a connective (if P, Q). Indeed, it should be mentioned that all Condition-Event items of the present experiment contained connectives such as si('if) or cuando('when') in the $\mathrm{S}_{1}$. Therefore, it is likely that when readers faced $S_{1}$ generated more expectations about the incoming information in $S_{2}$ than when they read the $S_{1}$ of the frequent relations (Conjunction and Concept Description), which do not have such salient feature. The same as in Language, these results do not provide evidence for the integration of the LE and SSE hypotheses. Rather, our data seem to suggest that the differences in the processing patterns can be explained only by the SSE hypothesis (Mulder, 2008).

The same conclusion is valid when we focus on the other least frequent coherence relation presented in Science, which was Concept Specification. This type of relation shows an informational complementarity between the events (or part of them) that are connected (Ibáñez et al., 2015). Thus, it could be inferred that the connection between both segments of this type of relation was more evident than in a Conjunction relation, which benefited its processing. Moreover, in a Concept Specification relation the content of $S_{2}$ specifies a specific concept presented in $S_{1}$. Therefore, it is possible that when participants faced $S_{2}$, they processed the information rapidly because the referent was already mentioned in $\mathrm{S}_{1}$. So, this short distance between the connected events facilitated its processing. In this sense, referential coherence plays a critical role in this 
type of relation. It has been proved that referential distance has a significant effect in processing texts of specialized discourse (Ibáñez, Santana \& Cornejo, 2015). The experimental items containing this type of relation in the present experiment included referential ties such as entre estos tipos... ('among these types...'), de todos ellos... ('of all of them...'), etc., which could have facilitated its processing.

\section{CONCLUSIONS}

Previous corpus-based studies (Ibáñez et al., 2019) have identified the most frequent coherence relations in Chilean primary school textbooks of different subjects. Based on the high frequency of certain relations, such as Conjunction and Concept description, it is reasonable to assume that to learn the declarative knowledge students are required to master, they are constantly demanded to successfully process and comprehend them. Therefore, the motivation of the current study was to determine whether the most frequent coherence relations facilitate students' processing and comprehension. Based on the integration of the Language Experience hypothesis (Nippold \& Taylor, 2002) and the Schematic Structure hypothesis (Mulder, 2008), it was expected that the most frequent relations are read faster and comprehended better than the least frequent ones.

Results obtained in the experiment revealed, in the first place, low levels of reading comprehension achievement. Overall reading scores obtained in the comprehension task were scarcely above $50 \%$ of success, which is in line with previous studies conducted in Chilean educational settings. In the case of the current study, our data suggest that Chilean students are clearly struggling in understanding the coherence relations that are by far the most frequent in their school textbooks. These results are worrisome because if students fail in successfully establishing the coherence relations through which knowledge is disseminated in school textbooks, there are good reasons to assume that their learning from text could be hampered.

When comparing the overall reading times and scores observed in the most frequent and least frequent conditions, results did not fully support our hypothesis. As expected, students' comprehension scores were higher when reading the most frequent relations, but they read the least frequent relations faster, which was opposite to what was expected. One possible explanation for this finding is students' reading skills. Based on the particularly low scores observed in the least frequent relations, it can be assumed that students' unfamiliarity with those relations led them to a shallow processing, which resulted in shorter reading times. Therefore, in this case, high speed seems to correlate with lower levels of achievement in comprehension. On the contrary, when students read the most frequent relations, it seems that they attempted to understand how to integrate the current segment with what they have read previously, resulting in longer reading times but in fairly higher scores. A second explanation for the faster reading times observed in the least frequent relations can be found in their nature. In general terms, these relations were causal (Act-Purpose, Action-Reason, Claim-Argument, 
Condition-Event) while the most frequent ones were non-causal (Conjunction and Concept description). In accordance with the SSE hypothesis, causal relations trigger more expectations about the type of information to come than non-causal ones. Then, when the new textual information presented in the second part fits in with such expectations, it will be processed with greater ease. So, for instance, when students read the Action part of the relation, they may expect to find in the next fragment why such action was carried out. Thus, when the information presented in the second segment fulfills those expectations, the process of integration seems to be facilitated, which in turn, leads to shorter reading times, as observed in our data. However, based on the scores obtained, it seems that even when the expectations triggered by causal relations were fulfilled, students failed in integrating the content of the segments into a solid and coherent mental representation. In consequence, regardless of the reasons why the least frequent relations were read faster, our results suggest that, at least in specialized contexts, shorter reading times do not necessarily result in a better comprehension, as also reported in other studies conducted with Chilean primary school students (Ibáñez et al., in press) and college students (Moncada, 2018). Furthermore, it can be argued that the high frequency of certain coherence relations only plays a facilitating effect on the quality of the product of comprehension (the mental representation) but not necessarily on the process involved in its construction. However, further studies are needed to support these ideas due to the poor overall results obtained by the students.

As already mentioned, data did not fully support the assumption that the integration of both hypotheses could explain the performance of the participants. It seems important, in this point, to consider that the reading skills of the participants and, consequently, their performance may mediate the expected effect. In this case, the apparent lack of consistency between comprehension and processing might not be so and could be explained assuming that high speed correlates with low performance.

Over the last decades, several studies have demonstrated the key role knowledge of global text structures plays in text comprehension, but little is known about the influence of knowledge of local structures, such as coherence relations. In consequence, the main contribution of the current study is that, to the best of our knowledge, it constitutes the first attempt to determine the extent to which highly frequent local structures (coherence relations) found in school textbooks affect student's comprehension. Besides, given that materials were extracted directly from actual school textbooks, it enabled us to evaluate how those coherence relations are processed by the audience they are ultimately aimed at. Consequently, our findings also contribute to the research on Chilean school textbooks by providing preliminary evidence of the difficulties students show to understand their most salient coherence relations. Further corpus based and experimental studies are required to examine how the most prominent linguistic features of school textbooks affect students' comprehension by, for instance, 
identifying their most frequent syntactic structures and measuring the ease with which they are processed and comprehended.

Among the limitations of this study, it should be mentioned the lack of additional measures that could have been performed before the self-paced experiment. Specifically, applying a reading placement test would have allowed us to select a more balanced sample than the current one, with subjects presenting different levels of comprehension (i.e., low, medium, and advanced). Thus, the data analysis would have taken into account the participants' comprehension performance as a baseline, obtaining more conclusive results. This is an important issue for future research. Notwithstanding this limitation, this work offers empirical evidence confirming partially the SSE hypothesis (Mulder, 2008), particularly regarding the comprehension of the most frequent coherence relations.

An issue that was not addressed in this study was to explore the effect of exposure to coherence relations on their processing and comprehension by selecting participants of different educational institutions according to their socioeconomic level. In the national context, it has been demonstrated that meaningful differences can exist between different educational entities. Students' private schools present better performance than those who study in public schools when processing and comprehending different types of coherence relations (Ibáñez et al., in press). Future research could be conducted to determine whether the effect of exposure to coherence relations varies depending on the educational background of participants. Furthermore, exploring other superior levels such as secondary school and university education would allow us to compare results in different contexts. In turn, it could also allow us to provide more empirical evidence into the LE and the SSE hypotheses in specialized contexts.

Although the nature of the current study was mainly exploratory, it offers empirical data into processing and comprehension in school contexts, which are available to be considered in future didactic implementations. A natural progression of this work is to analyze in detail those factors that might influence the processing of the most and the least frequent relations. Along with this, we believe that future research should implement the use of other complementary methodologies. For instance, eye-tracking can be an optimal methodology not only to corroborate the findings obtained in the current study but also to identify the linguistic patterns that facilitate or difficult the processing of these coherence relations.

\section{ACKNOWLEDGMENTS}

The first and second authors' work was supported by a grant awarded by Fondecyt (Project 1201440) from the National Research and Development Agency (ANIDChile). The third author's work was funded by Postdoctoral Grant 3210252 from the same institution. 


\section{REFERENCES}

Afflerbach, P. (1986). The influence of prior knowledge on expert readers' importance assignment processes. In J. Niles \& R. Lalik (Eds.), National reading conference yearbook. Vol. 35 solving problems in literacy: Learners, teachers and researchers (pp 3040). New York: National Reading Conference.

Agencia de Calidad de la Educación. (2014). Informe nacional resultados Chile PISA 2012. Santiago, Chile: División de Estudios, Departamento de Estudios Internacionales, Agencia de Calidad de la Educación [on line]. Retrieved from: http://archivos.agenciaeducacion.cl/Informe_Nacional_Resultados_Chile PI SA 2012.pdf

Agencia de la Calidad de la Educación (2016). Informe nacional resultados SIMCE 2015. Santiago, Chile [on line]. Retrieved https://educacion2020.cl/documentos/resultados-simce-2015

Allen, L. \& McNamara, D. (2020). Defining deep reading comprehension for diverse readers. In E. Birr, P. Afflerbach, P. Enciso \& N. Lesaux (Eds.), Handbook of reading research. Volume V. (pp. 261-276). New York: Routledge.

Anderson, R. C. \& Pearson, P. D. (1984). A schema-theoretic view of basic processes in reading comprehension. In P. D. Pearson, R. Barr, M. L. Kamil \& P. Mosenthal (Eds.), Handbook of reading research (pp. 255291). New York: Longman.

Armbruster, B. B. (2004). Considerate texts. In D. Lapp, J. Flood \& N. Farnan (Eds.), Content area reading and learning: Instructional strategies. 2nd Edition. (pp. 47-58). Mahwah, NJ: Erlbaum.

Armbruster, B. B., Anderson, T. H. \& Ostertag, J. (1987). Does text structure/summarization instruction facilitate learning from expository text? Reading research quarterly, 331-346.

Arnold, J. E., Strangmann, I. M., Hwang, H., Zerkle, S. \& Nappa, R. (2018). Linguistic experience affects pronoun interpretation. Journal of Memory and Language, 102, 41-54.

Baddeley, A. (1992). Working memory: The interface between memory and cognition. Journal of cognitive neuroscience, 4(3), 281-288.

Beker, K., Jolles, D. \& van den Broek, P. (2017). Meaningful learning from texts. In J. León \& I. Escudero (Eds.), Reading comprehension in educational settings (pp 16-29). Amsterdam: John Benjamins. 
Best, R. M., Floyd, R. G. \& McNamara, D. S. (2008). Differential competencies contributing to children's comprehension of narrative and expository texts. Reading psychology, 29(2), 137-164.

Bogaerds-Hazenberg, S. T., Evers-Vermeul, J. \& van den Bergh, H. (2021). A metaanalysis on the effects of text structure instruction on reading comprehension in the upper elementary grades. Reading Research Quarterly, 56(3), 435-462.

Britton, B. K., Stimson, M., Stennett, B. \& Gülgöz, S. (1998). Learning from instructional text: Test of an individual-differences model. Journal of Educational Psychology, 90(3), 476-491.

Cervetti, G. \& Wright, T. (2020). The role of knowledge in understanding and learning from text. In E. Birr, P. Afflerbach, P. Enciso \& N. Lesaux (Eds.), Handbook of Reading Research. Volumen V. (pp. 237-260). New York: Routledge.

Dickson, S. V., Simmons, D. C. \& Kame'enui, E. J. (1995). Text organization and its relation to reading comprehension: A synthesis of the research (Technical Report No. 17). Eugene: National Center to Improve the Tools of Educators, University of Oregon.

Duke, N. K., Pearson, P. D., Strachan, S. L. \& Billman, A. K. (2011). Essential elements of fostering and teaching reading comprehension. In S. J. Samuels \& A. E. Farstrup (Eds.), What research has to say about reading instruction. 4th Edition. (pp. 51-93). Newark, DE: International Reading Association.

Evers-Vermeul, J. \& Sanders, T. (2009). The emergence of Dutch connectives; how cumulative cognitive complexity explains the order of acquisition. Journal of Child Language, 36(4), 829-854.

Figueroa, S. \& Tobías, M. (2018). La importancia de la comprensión lectora: Un análisis en alumnado de educación básica en Chile. Revista de Educación de la Universidad de Granada, 25, 113-129.

Gallego, J. L., Figueroa, S. \& Rodríguez, A. (2019). La comprensión lectora de escolares de educación básica. Literatura y lingüistica, 40, 187-208.

García, J. R., Bustos, A. \& Sánchez, E. (2015). The contribution of knowledge about anaphors, organisational signals and refutations to reading comprehension. Journal of Research in Reading, 38(4), 405-427.

Gersten, R., Fuchs, L. S., Williams, J. P. \& Baker, S. (2001). Teaching reading comprehension strategies to students with learning disabilities: A review of research. Review of educational research, 71(2), 279-320. 
Goldman, S. \& George, M. A. (2019). What are we reading for? A disciplinary literacy perspective on purpose. In K. Millis, D. Long, J. Magliano \& K. Wiemer (Eds.), Deep Comprehension. Multidisciplinary approaches to understanding, Enhancing and measuring Comprehension (pp. 80-96). New York: Routledge.

Gollan, T., Slattery, T., Goldenberg, D., Van Assche, E., Duyck, W. \& Rayner, K. (2011). Frequency drives lexical access in reading but not in speaking: The frequency-lag hypothesis. Journal of Experimental Psychology: General, $140(2), 186$.

Graesser, A. C. (2015). Deeper learning with advances in discourse science and technology. Policy Insights from the Behavioral and Brain Sciences, 2(1), 42-50.

Hoek, J., Zufferey, S., Evers-Vermeul, J. \& Sanders, T. (2017). Cognitive complexity and the linguistic marking of coherence relations: A parallel corpus study. Journal of Pragmatics, 121, 113-131.

Ibáñez, R., Moncada, F. \& Santana, A. (2015). Variación disciplinar en el discurso académico de la Biología y del Derecho: Un estudio a partir de las relaciones de coherencia. Onomázein, 32, 101-131.

Ibáñez, R., Santana, A. \& Cornejo, F. (2015). La dirección y la distancia en el establecimiento de la coherencia referencial durante el procesamiento de textos académicos escritos en español. Revista de Lingüistica Teórica y Aplicada, 53(2), 145-170.

Ibáñez, R., Moncada, F., Cornejo, F. \& Arriaza, V. (2017). Los géneros del conocimiento en textos escolares de educación primaria. Calidoscopio, 15(3), 462476.

Ibáñez, R., Moncada, F. \& Cárcamo, B. (2019). Coherence Relations in Primary School Textbooks Variation across School Subjects. Discourse Processes, 56(4), 1-22.

Ibáñez, R., Moncada, F. \& Cárcamo, B. (In press). Texto escolar y comprensión. Efecto de las características de las relaciones de coherencia en estudiantes con diferente nivel socioeconómico. Revista Española de Lingüistica Aplicada.

Kendeou, P. \& Van den Broek, P. (2007). The effects of prior knowledge and text structure on comprehension processes during reading of scientific texts. Memory \& Cognition, 35(7), 1567-1577.

Kendeou, P. \& O’Brien, E. (2016). Prior knowledge: Acquisition and revision. In P. Afflerbach (Ed.), Handbook of individual differences in reading. Reader, Text and Context (pp. 151-163). New York: Routledge. 
Kendeou, P. \& O’Brien, E. (2018). Reading comprehension theories. A view from the top down. In M. Schober, D. Rapp \& A. Britt (Eds.), The Routledge Handbook of discourse processes. $2^{\text {nd }}$ Edition. (pp. 7-21). New York: Routledge.

Kendeou, P., Rapp, D. \& Van den Broek, P. (2003). The influence of reader's prior knowledge on text comprehension and learning from text. Progress in education, 13, 189-209.

Kintsch, W. (1988). The role of knowledge in discourse comprehension: A construction-integration model. Psychological review, 95(2), 163.

Kintsch, W. (1998). Comprehension. A paradigm for cognition. Cambridge: Cambridge University Press.

Kintsch, W. \& van Dijk, T. A. (1978). Toward a model of text comprehension and production. Psychological review, 85(5), 363.

Kleijn, S. (2018). Clozing in on readability: How linguistic features affect and predict text comprehension and on-line processing. Unpublished doctoral dissertation, Utrecht University, Utrecht, The Netherlands.

Kleijn, S., Pander Maat, H. L. \& Sanders, T. (2019). Comprehension effects of connectives across texts, readers, and coherence relations. Discourse Processes, 56(5-6), 447-464.

Knoepke, J., Richter, T., Isberner, M. B., Naumann, J., Neeb, Y. \& Weinert, S. (2017). Processing of positive-causal and negative-causal coherence relations in primary school children and adults: A test of the cumulative cognitive complexity approach in German. Journal of child language, 44(2), 297-328.

Levorato, M. C. \& Cacciari, C. (1992). Children's comprehension and production of idioms: The role of context and familiarity. Journal of Child Language, 19(2), 415433.

MacDonald, M. C. (2013). How language production shapes language form and comprehension. Frontiers in psychology, 4, 226.

Magliano, J., Higgs, K. \& Millis, K. (2019). Deep comprehension of text revealed by talking and writing while reading. In K. Millis, D. Long, J. Magliano \& K. Wiemer (Eds.), Deep comprehension. Multidisciplinary approaches to understanding, Enhancing and measuring Comprehension (pp. 253-264). New York: Routledge.

Mann, W. C. \& Thompson, S. (1986). Relational propositions in discourse. Discourse processes, 9(1), 57-90. 
McNamara, D., Ozuru, Y. \& Floyd, R. (2011). Comprehension challenges in the fourth grade: The roles of text cohesion, text genre, and readers' prior knowledge. International electronic journal of elementary education, 4(1), 229-257.

McNamara, D., Kintsch, E., Songer, N. \& Kintsch, W. (1996). Are good texts always better? Interactions of text coherence, background knowledge, and levels of understanding in learning from text. Cognition and instruction, 14(1), 1-43.

McNamara, D., Jacovina, M. \& Allen, L. (2016). High order thinking in comprehension. In P. Afflerbach (Ed.), Handbook of individual differences in reading. Reader, Text and Context (pp. 164-176). New York: Routledge.

Meyer, B. J. (1975). The organization of prose and its effects on memory. Amsterdam: North Holland.

Meyer, B. \& Freedle, R. O. (1984). Effects of discourse type on recall. American Educational Research Journal, 21(1), 121-143.

Meyer, B. \& Rice, G. E. (1984). The structure of text. In P. D. Pearson, R. Barr, M. L. Kamil \& P. Mosenthal (Eds.), Handbook of reading research (pp. 319-351). New York: Longman.

Meyer, B. \& Poon, L. W. (2001). Effects of structure strategy training and signaling on recall of text. Journal of educational psychology, 93(1), 141-159.

Meyer, B. \& Ray, M. N. (2011). Structure strategy interventions: Increasing reading comprehension of expository text. International Electronic Journal of Elementary Education, 4(1), 127-152.

Meyer, B., Brandt, D. M. \& Bluth, G. J. (1980). Use of top-level structure in text: Key for reading comprehension of ninth-grade students. Reading Research Quarterly, $16,72-103$.

Meyer, B., Young, C. J. \& Bartlett, B. J. (1989). Memory improved: Enhanced reading comprehension and memory across the life span through strategic text structure. Hillsdale, NJ: Erlbaum.

Miller, A. C. \& Keenan, J. M. (2009). How word decoding skill impacts text memory: The centrality deficit and how domain knowledge can compensate. Annals of dyslexia, 59(2), 99.

Moncada, F. (2018). Interacción entre conectores y conocimiento previo en el procesamiento de la coherencia causal. Círculo de Lingüistica Aplicada a la Comunicación, 76, 179-196. 
Mulder, G. (2008). Understanding causal coherence relations. Unpublished doctoral dissertation, Utrecht University, Utrecht, The Netherlands.

Mulder, G. \& Sanders, T. (2012). Causal coherence relations and levels of discourse representation. Discourse Processes, 49(6), 501-522.

Nippold, M. A. \& Haq, F. S. (1996). Proverb comprehension in youth: The role of concreteness and familiarity. Journal of Speech, Language, and Hearing Research, 39(1), 166-176.

Nippold, M. A., Moran, C. \& Schwarz, I. E. (2001). Idiom understanding in preadolescents: Synergy in action. American Journal of Speech and Language Pathology, 10(2001), 169-179.

Nippold, M. A. \& Taylor, C. L. (2002). Judgments of idiom familiarity and transparency: A comparison of children and adolescents. Journal of Speech, Language, \& Hearing Research, 45, 384-391.

O'Reilly, T. \& McNamara, D. S. (2007). Reversing the reverse cohesion effect: Good texts can be better for strategic, high-knowledge readers. Discourse processes, 43(2), 121-152.

O’Reilly, T., Sabatini, J. \& Wang, Z. (2019). Using Scenario-Based Assessments to measure deep learning. In K. Millis, D. Long, J. Magliano \& K. Wiemer (Eds.), Deep Comprehension. Multidisciplinary approaches to understanding, Enhancing and measuring Comprehension (pp. 197-208). New York: Routledge.

O'Brien, E. \& Cook, A. (2015). Models of discourse comprenension. In A. Pollatsek \& R. Treiman (Eds.), Handbook on reading (pp. 217-231). New York: Oxford University Press.

Ogle, D. \& Blachowicz, C. L. (2002). Beyond literature circles: Helping students comprehend informational texts. Comprehension instruction: Research-based best practices, 259-274.

Ozuru, Y., Dempsey, K. \& McNamara, D. S. (2009). Prior knowledge, reading skill, and text cohesion in the comprehension of science texts. Learning and instruction, 19(3), 228-242.

Parodi, G., Peronard, M. \& Ibáñez, R. (2010). Saber leer. Madrid: Editorial Aguilar.

Parodi, G., de León, T., Julio, C. \& Burdiles, G. (2019). Generación Google o generación Gutenberg: Hábitos y propósitos de lectura en estudiantes universitarios chilenos. Comunicar, 27(58), 85-94.

Pezoa, J. P. \& Orellana, P. (2021). La relación entre comprensión lectora y vocabulario receptivo en estudiantes chilenos: Un estudio exploratorio. Ocnos, 20(2), 7-20. 
Pyle, N., Vásquez, A. C., Lignugaris/Kraft, B., Gillam, S., Reutzel, D. R., Olszewski, A. \& Pyle, D. (2017). Effects of expository text structure interventions on comprehension: A meta- analysis. Reading Research Quarterly, 52, 469-501.

R Core Team. (2018). R: A Language and Environment for Statistical Computing. R Foundation for Statistical Computing, Vienna [on line]. Retrieved from: https://www.Rproject.org

Ray, M. N. \& Meyer, B. J. (2011). Individual differences in children's knowledge of expository text structures: A review of literature. International Electronic Journal of Elementary Education, 4(1), 67-82.

Rayner, K. \& Raney, G. E. (1996). Eye movement control in reading and visual search: Effects of word frequency. Psychonomic Bulletin \& Review, 3(2), 245-248.

Sanders, T. (2005). Coherence, causality and cognitive complexity in discourse. In Proceedings/Actes SEM-05, First International Symposium on the exploration and modelling of meaning (pp. 105-114). Toulouse: University of Toulouse-le-Mirail.

Sanders, T. \& Noordman, L. G. (2000). The role of coherence relations and their linguistic markers in text processing. Discourse processes, 29(1), 37-60.

Sanders, T., Spooren, W. P. \& Noordman, L. G. (1992). Toward a taxonomy of coherence relations. Discourse processes, 15(1), 1-35.

Santana, A., Ibáñez, R., Moncada, F. \& Zamora, J. (2021). Causal connective expressions in textbooks written in Spanish: A comparative study of four primary school subjects. Journal of Pragmatics, 182, 104-117.

Scholman, M. C., Demberg, V. \& Sanders, T. J. (2020). Individual differences in expecting coherence relations: Exploring the variability in sensitivity to contextual signals in discourse. Discourse Processes, 57(10), 844-861.

Shanahan, T., Callison, K., Carriere, C., Duke, N. K., Pearson, P. D., Schatschneider, C. \& Torgesen, J. (2010). Improving reading comprehension in kindergarten through 3rd grade: A practice guide (NCEE 2010-4038). Washington, DC: National Center for Education Evaluation and Regional Assistance, Institute of Education Sciences, U.S. Department of Education.

Shapiro, A. M. (2004). How including prior knowledge as a subject variable may change outcomes of learning research. American Educational Research Journal, 41(1), 159189.

Singer, M., Graesser, A. \& Trabasso, T. (1994). Minimal or global inference during reading. Journal of Memory and Language, 33(4),421-441. 
Slater, W. H. (1985). Teaching expository text structure with structural organizers. Journal of reading, 28(8), 712-718.

Solomon, R. L. \& Howes, D. H. (1951). Word frequency, personal values, and visual duration thresholds. Psychological Review, 58(4), 256.

Tanenhaus, M. K. \& Trueswell, J. C. (1995). Sentence comprehension. In J. Miller \& P. Eimas (Eds.), Speech, Language, and communication (pp. 217-262). San Diego: Academic Press.

Teasdale, J. (2020). Processing differences in additive relations. Finding complexity in 'simple' structures. Unpublished master's thesis, Utrecht University, Utrecht, The Netherlands.

Traxler, M. J., Bybee, M. D. \& Pickering, M. J. (1997). Influence of connectives on language comprehension: Eye tracking evidence for incremental interpretation. The Quarterly Journal of Experimental Psychology Section A, 50(3), 481-497.

Traxler, M. J., Sanford, A. J., Aked, J. P. \& Moxey, L. M. (1997). Processing causal and diagnostic statements in discourse. Journal of Experimental Psychology: Learning, Memory, and Cognition, 23(1), 88.

Van den Broek, P. \& Kendeou, P. (2017). Development of reading comprehension. Theories of reading development, 283-306.

Van den Broek, P., Risden, K., Fletcher, C. R. \& Thurlow, R. (1996). A landscape view of reading: Fluctuating patterns of activation and the construction of a stable memory representation. In B. Britton \& A. Graesser (Eds.), Models of understanding text (pp. 165-187). Hillsdale, NJ: Lawrance Erlbaum.

Van Dijk, T. A. \& Kintsch, W. (1983). Strategies of discourse comprehension. New York: Academic.

Van Silfhout, G., Evers-Vermeul, J. \& Sanders, T. (2014). Establishing coherence in schoolbook texts: How connectives and layout affect students' text comprehension. Dutch Journal of Applied Linguistics, 3(1), 1-29.

Van Silfhout, G., Evers-Vermeul, J. \& Sanders, T. (2015). Connectives as processing signals: How students benefit in processing narrative and expository texts. Discourse Processes, 52(1), 47-76.

Weisberg, R. \& Balajthy, E. (1989). Transfer effects of instructing poor readers to recognize expository text structure. National Reading Conference Yearbook, 38, 279286.

Wiley, J. \& Myers, J. L. (2003). Availability and accessibility of information and causal inferences from scientific text. Discourse Processes, 36(2), 109-129. 
Williams, J. P., Pollini, S., Nubla-Kung, A. M., Snyder, A. E., García, A., Ordynans, J. G. \& Atkins, J. G. (2014). An intervention to improve comprehension of cause/effect through expository text structure instruction. Journal of Educational Psychology, 106(1), 1-17.

Wolfe, M. B. \& Woodwyk, J. M. (2010). Processing and memory of information presented in narrative or expository texts. British Journal of Educational Psychology, $80(3), 341-362$.

Zufferey, S. \& Gygax, P. (2019). Roger broke his tooth. However, he went to the dentist: Why some readers struggle to evaluate wrong (and right) uses of connectives. Discourse Processes, 57(2), 184-200.

Zufferey, S. \& Gygax, P. (2020). Do teenagers know how to use connectives from the written mode? Lingua, 234, 102779.

Zwaan, R. A. (1994). Effect of genre expectations on text comprehension. Journal of experimental psychology: Learning, memory, and cognition, 20(4), 920-933.

Zwaan, R. A. \& Singer, M. (2003). Text comprehension. In A. Graesser, M. A. Gernsbacher \& S. R. Goldman (Eds.), Handbook of discourse processes (pp. 83-121). Hillsdale, NJ: Erlbaum. 


\begin{tabular}{|c|c|}
\hline HISTORY & \\
\hline \multirow{6}{*}{ Conjunction } & $\begin{array}{l}\text { 1. Por las mañanas, en la costa, se forma una neblina espesa llamada camanchaca. En el } \\
\text { altiplano, durante el verano, se producen fuertes lluvias y tormentas conocidas como } \\
\text { invierno altiplánico. }\end{array}$ \\
\hline & $\begin{array}{l}\text { 'In the mornings, on the coast, a thick fog called camanchaca forms. In the altiplano, during the summer, } \\
\text { there are heavy rains and storms known as altiplano winter.' }\end{array}$ \\
\hline & $\begin{array}{l}\text { 2. La conquista del Imperio inca sirvió como punto de partida para las exploraciones de } \\
\text { otras regiones de Sudamérica. Los rumores sobre riquezas al sur del Imperio inca, } \\
\text { incitaron a algunos españoles a avanzar hacia esos territorios. }\end{array}$ \\
\hline & $\begin{array}{l}\text { 3. La exportación (ventas al extranjero) del salitre originó grandes riquezas para Chile. A } \\
\text { principios del siglo XX gran parte del ingreso del Estado provenían de la exportación de } \\
\text { este mineral. }\end{array}$ \\
\hline & $\begin{array}{l}\text { 4. En el antiguo Egipto, el río Nilo fue el principal posibilitador de gran parte de la } \\
\text { actividad agrícola. Varios faraones extendieron el territorio y la influencia de Egipto más } \\
\text { allá del Nilo, como Siria y Etiopía. }\end{array}$ \\
\hline & $\begin{array}{l}\text { 5. El voto es un poder propio de los ciudadanos a través del cual se toman diversas } \\
\text { decisiones políticas. En Chile, desde el retorno a la democracia, se estableció la } \\
\text { inscripción en el registro electoral como voluntaria. }\end{array}$ \\
\hline \multirow{6}{*}{$\begin{array}{l}\text { Concept } \\
\text { Description }\end{array}$} & $\begin{array}{l}\text { 1. La Cordillera de la Costa mantiene el nombre de Nahuelbuta. Desde el río Toltén al } \\
\text { sur, se le conoce comúnmente con el nombre de Mahuidanche. }\end{array}$ \\
\hline & $\begin{array}{l}\text { 'The Coastal Range keeps the name Nabuelbuta. From the Tolten River to the south, it is commonly } \\
\text { known as Mabuidanche.' }\end{array}$ \\
\hline & $\begin{array}{l}\text { 2. La Zona Sur se extiende desde el río Biobío hasta el golfo de Corcovado, al sur de la } \\
\text { isla grande de Chiloé. Esta área se caracteriza por sus verdes paisajes, numerosos ríos y } \\
\text { lagos, majestuosos volcanes y sus tradiciones culturales. }\end{array}$ \\
\hline & $\begin{array}{l}\text { 3. Los romanos sometieron a su dominio a casi todo el mundo. Poseían un poderoso } \\
\text { imperio inmensamente más grande que todos aquellos que habían surgido antes de este. }\end{array}$ \\
\hline & $\begin{array}{l}\text { 4. En } 1910 \text { se contaban en la ciudad de Santiago más de } 1.600 \text { conventillos. Estas } \\
\text { viviendas eran fuente de enfermedades infecciosas tales como el cólera, la viruela, el tifus } \\
\text { y la sífilis. }\end{array}$ \\
\hline & $\begin{array}{l}\text { 5. La zona del Norte Chico se extiende desde el río Copiapó hasta el río Aconcagua. Esta } \\
\text { área se caracteriza por sus amplias y extensas planicies litorales, fértiles valles y sus cielos } \\
\text { precordilleranos despejados. }\end{array}$ \\
\hline \multicolumn{2}{|c|}{ LANGUAGE } \\
\hline \multirow{6}{*}{ Conjunction } & $\begin{array}{l}\text { 1. Los mitos griegos eran relatos orales originarios de tiempos remotos. El escritor latino } \\
\text { Ovidio narró en su libro Metamorfosis una cantidad superior a doscientos mitos. }\end{array}$ \\
\hline & $\begin{array}{l}\text { 'Greek myths were oral stories originating from ancient times. The Latin writer Ovid narrated in his } \\
\text { book. Metamorphoses more than two hundred myths.' }\end{array}$ \\
\hline & $\begin{array}{l}\text { 2. El acto corresponde a cada una de las partes en que se divide la obra. Normalmente el } \\
\text { número de actos coincide con la estructura interna de la obra dramática. }\end{array}$ \\
\hline & $\begin{array}{l}\text { 3. En la obra teatral, el cierre del telón determina el término de un acto. En la actualidad } \\
\text { es común que las obras dramáticas se estructuren en un solo acto. }\end{array}$ \\
\hline & $\begin{array}{l}\text { 4. Las mitologías constituyen un gran relato ordenado por una manera especial de } \\
\text { entender el mundo. Los antiguos griegos crearon una mitología donde dioses eran } \\
\text { inmortales y de apariencia humana. }\end{array}$ \\
\hline & $\begin{array}{l}\text { 5. La acción es el conjunto de sucesos ordenados que se cuentan en la narración. El } \\
\text { ambiente incluye el lugar, espacio, tiempo y atmósfera donde se llevan a cabo las acciones. }\end{array}$ \\
\hline \multirow{4}{*}{$\begin{array}{l}\text { Concept } \\
\text { Description }\end{array}$} & $\begin{array}{l}\text { 1. Las leyendas son relatos fantásticos que suelen ocurrir en un tiempo no muy lejano. } \\
\text { Este tipo de relato se transmiten de boca en boca y de generación en generación. }\end{array}$ \\
\hline & $\begin{array}{l}\text { 'Legends are fantastic stories that usually take place in a not-too-distant time. This type of story is passed } \\
\text { on by word of mouth and from generation to generation.' }\end{array}$ \\
\hline & $\begin{array}{l}\text { 2. El hablante lírico es la voz que crea el autor (poeta) para hablar en el poema. Esta voz } \\
\text { transmite las ideas, los deseos, los estados de ánimo, los sentimientos, etc. }\end{array}$ \\
\hline & $\begin{array}{l}\text { 3. La escena es la unidad menor de la obra dramática. Se determina por la entrada o la } \\
\text { salida de cualquier personaje durante la representación. }\end{array}$ \\
\hline
\end{tabular}




\begin{tabular}{|c|c|}
\hline & $\begin{array}{l}\text { 4. Un reportaje es un relato objetivo, informativo y documentado sobre una serie de } \\
\text { hechos. En algunos casos, se suele asemejar en gran medida a una noticia en profundidad. } \\
\text { 5. El Realismo es una corriente artística y literaria desarrollada principalmente a fines del } \\
\text { siglo XIX. Su objetivo era reflejar la realidad tal cual es a través del arte y del lenguaje. }\end{array}$ \\
\hline \multicolumn{2}{|l|}{ SCIENCE } \\
\hline \multirow{6}{*}{ Conjunction } & $\begin{array}{l}\text { 1. La temperatura de la superficie de Marte es muy baja, alrededor de }-50{ }^{\circ} \mathrm{C} \text {. A partir de } \\
\text { recientes estudios se supone que en este planeta existió agua líquida. }\end{array}$ \\
\hline & $\begin{array}{l}\text { 'The surface temperature of Mars is very low, around }-50{ }^{\circ} \mathrm{C} \text {. From recent studies, it is assumed that } \\
\text { liquid water existed on this planet.' }\end{array}$ \\
\hline & $\begin{array}{l}\text { 2. Las hormonas femeninas son estrógenos y progesterona. A la hormona sexual } \\
\text { masculina se le conoce con el nombre de testosterona. }\end{array}$ \\
\hline & $\begin{array}{l}\text { 3. Las vitaminas sólo pueden ser obtenidas a través de los alimentos. El aporte extra de } \\
\text { minerales debe ser siempre indicado por un médico especialista en nutrición. }\end{array}$ \\
\hline & $\begin{array}{l}\text { 4. El monóxido de carbono }(\mathrm{CO}) \text { no posee color ni olor. Las chimeneas o braseros y los } \\
\text { automóviles liberan de manera constante este tipo de gas. }\end{array}$ \\
\hline & $\begin{array}{l}\text { 5. Las industrias en sus procesos productivos utilizan agua. La composición de los } \\
\text { líquidos residuales varía con el tipo de industria y proceso realizado. }\end{array}$ \\
\hline \multirow{6}{*}{$\begin{array}{l}\text { Concept } \\
\text { Description }\end{array}$} & $\begin{array}{l}\text { 1. A veces, la lava sale de manera violenta junto con grandes masas de gases y rocas } \\
\text { incandescentes. En otras ocasiones, sucede que fluye de manera más suave, sin que haya } \\
\text { grandes explosiones. }\end{array}$ \\
\hline & $\begin{array}{l}\text { 'Sometimes, lava flows out violently along with large masses of gases and incandescent rocks. At other } \\
\text { times, it flows more smoothly, without large explosions.' }\end{array}$ \\
\hline & $\begin{array}{l}\text { 2. Las proteínas forman parte de todos los tejidos, como la sangre, la piel y los músculos. } \\
\text { Cumplen un rol que es considerado como fundamental en su desarrollo, mantención y } \\
\text { reparación. }\end{array}$ \\
\hline & $\begin{array}{l}\text { 3. Los carbohidratos son llamados también azúcares. Son uno de los tres principales } \\
\text { alimentos que proveen de energía a nuestro cuerpo. }\end{array}$ \\
\hline & $\begin{array}{l}\text { 4. Las aguas servidas son aquellas aguas previamente utilizadas. Son una mezcla de agua } \\
\text { y de residuos arrastrados provenientes de las casas y del comercio. }\end{array}$ \\
\hline & $\begin{array}{l}\text { 5. La atmósfera, capa gaseosa que rodea a la Tierra, está conformada por una gran } \\
\text { cantidad de gases en continuo movimiento. La gran cantidad de gases que la constituyen } \\
\text { están en un continuo movimiento. }\end{array}$ \\
\hline
\end{tabular}

\section{APPENDIX B. Experimental items corresponding to the least frequent relations. 4}

\begin{tabular}{|c|c|}
\hline \multicolumn{2}{|l|}{ HISTORY } \\
\hline \multirow[t]{6}{*}{$\begin{array}{c}\text { Claim- } \\
\text { Argument }\end{array}$} & $\begin{array}{l}\text { 1. Diego Portales fue uno de los personajes más importantes del siglo XIX, ya que su } \\
\text { participación en la política fue clave en los acontecimientos transcurridos en las } \\
\text { décadas de } 1820 \text { y } 1830 \text {. }\end{array}$ \\
\hline & $\begin{array}{l}\text { 'Diego Portales was one of the most important people of the } 19 \text { th century since his participation in } \\
\text { politics was key in the } 1820 \text { s and } 1830 \text { s events.' }\end{array}$ \\
\hline & $\begin{array}{l}\text { 2. Nos parece que la pintura constituye una fuente histórica importante, ya que muestra } \\
\text { en detalle elementos y aspectos diversos acerca de las costumbres y tradiciones } \\
\text { características de una determinada época. }\end{array}$ \\
\hline & $\begin{array}{l}\text { 3. Para nuestro país contar con una amplia diversidad de recursos naturales es muy } \\
\text { importante, ya que el crecimiento económico ha estado siempre vinculado tanto a la } \\
\text { extracción como a la comercialización de recursos naturales. }\end{array}$ \\
\hline & $\begin{array}{l}\text { 4. En los últimos años, la pesca en Chile ha vivido un momento de gran crisis, ya que, } \\
\text { al conocido colapso del jurel y la merluza, ahora se suma la falta de la sardina y } \\
\text { anchoveta. }\end{array}$ \\
\hline & $\begin{array}{l}\text { 5. A partir de los años } 500 \text { a.C., la identidad de la religión judía se fortaleció } \\
\text { considerablemente, ya que la Ley de Moisés, el Templo de Jerusalén y la lectura de la } \\
\text { palabra eran los pilares del judaísmo. }\end{array}$ \\
\hline $\begin{array}{c}\text { Event } \\
\text { Description }\end{array}$ & $\begin{array}{l}\text { 1. Durante la Edad Media, el espacio alrededor del mar Mediterráneo se dividió en tres } \\
\text { grandes zonas: la Europa cristiana, el Imperio bizantino y el Imperio musulmán. La }\end{array}$ \\
\hline
\end{tabular}




\begin{tabular}{|c|c|}
\hline & $\begin{array}{l}\text { división es recordada por las complejas relaciones entre estas culturas, con períodos } \\
\text { tensos y otros de intercambios. }\end{array}$ \\
\hline & $\begin{array}{l}\text { 'During the Middle Ages, the area around the Mediterranean Sea was divided into three large zones: } \\
\text { Christian Europe, the Byzantine Empire, and the Muslim Empire. The division is remembered for } \\
\text { the complex relations between these cultures, with periods of tension and others of exchange.' }\end{array}$ \\
\hline & $\begin{array}{l}\text { 2. Se incorporó en América mano de obra de origen africano bajo el régimen de } \\
\text { esclavitud. Este régimen se convirtió rápidamente en un gran negocio para los dueños } \\
\text { de plantaciones y para comerciantes. }\end{array}$ \\
\hline & $\begin{array}{l}\text { 3. Desde la época colonial, se consolida la unión cultural de los pueblos europeos, } \\
\text { indígenas americanos y africanos. En el territorio chileno, este proceso también se } \\
\text { experimentó con fuerza, especialmente entre españoles y mapuches. }\end{array}$ \\
\hline & $\begin{array}{l}\text { 4. En el siglo XV, España y Portugal inician un proceso de expansión comercial y } \\
\text { territorial. Este proceso histórico, causante de la llegada de Cristóbal Colón a América, } \\
\text { no obedeció a una única causa. }\end{array}$ \\
\hline & $\begin{array}{l}\text { 5. En gran parte de América, los nuevos Estados comenzaron a experimentar cambios } \\
\text { importantes. Estos cambios implicaron que la mayoría de los nuevos Estados optaran } \\
\text { directamente por la creación de repúblicas. }\end{array}$ \\
\hline \multicolumn{2}{|l|}{ LANGUAGE } \\
\hline \multirow[t]{6}{*}{ Act-Purpose } & $\begin{array}{l}\text { 1. Se usan puntos suspensivos para representar un momento de suspenso, duda, temor } \\
\text { o vacilación durante la narración de un relato. }\end{array}$ \\
\hline & $\begin{array}{l}\text { 'Suspense points are used to represent a moment of suspense, doubt, fear, or hesitation during the } \\
\text { telling of a story.' }\end{array}$ \\
\hline & $\begin{array}{l}\text { 2. El narrador recurre a la descripción para construir de manera detallada el ambiente } \\
\text { en el que ocurren las acciones en una narración. }\end{array}$ \\
\hline & $\begin{array}{l}\text { 3. Las citas y referencias se utilizan frecuentemente en el mundo universitario y } \\
\text { científico para aprovechar la información producida por los investigadores y } \\
\text { estudiosos de diversas partes del mundo. }\end{array}$ \\
\hline & $\begin{array}{l}\text { 4. En los relatos de misterio o terror, el autor suele modificar el orden cronológico de } \\
\text { los acontecimientos para causar un efecto de suma sorpresa o extrema extrañeza en } \\
\text { cualquier tipo de lector. }\end{array}$ \\
\hline & $\begin{array}{l}\text { 5. Las obras del género lírico emplean varios recursos estilísticos para lograr tanto un } \\
\text { efecto de sentido como también cierta musicalidad en el mensaje del poema. }\end{array}$ \\
\hline \multirow[t]{6}{*}{$\begin{array}{c}\text { Claim- } \\
\text { Argument }\end{array}$} & $\begin{array}{l}\text { 1. En las instrucciones predomina la función apelativa del lenguaje, ya que su finalidad } \\
\text { es que el receptor ejecute una determinada acción organizada en etapas o pasos. }\end{array}$ \\
\hline & $\begin{array}{l}\text { 'In the instructions, the appellative function of the language predominates since its purpose is that the } \\
\text { receiver executes a certain action organized in stages or steps.' }\end{array}$ \\
\hline & $\begin{array}{l}\text { 2. En los textos líricos predomina la función expresiva del lenguaje, ya que el autor o } \\
\text { autora desea transmitir los sentimientos y emociones que está sintiendo en el } \\
\text { momento. }\end{array}$ \\
\hline & $\begin{array}{l}\text { 3. Saber cuál es el contexto de una obra permite comprenderla mejor, ya que esta } \\
\text { información permite entender, entre otras cosas, el comportamiento de los diversos } \\
\text { personajes de la obra. }\end{array}$ \\
\hline & $\begin{array}{l}\text { 4. Al interior de una narración, no todos los personajes tienen el mismo desarrollo, ya } \\
\text { que hay algunos que tienen una personalidad que es considerablemente más compleja } \\
\text { que la de otros. }\end{array}$ \\
\hline & $\begin{array}{l}\text { 5. Las citas y referencias son elementos muy importantes en los trabajos de } \\
\text { investigación, ya que, gracias a ellas, los escritores pueden incluir en sus trabajos la } \\
\text { información de otros investigadores. }\end{array}$ \\
\hline \multicolumn{2}{|l|}{ SCIENCE } \\
\hline \multirow[t]{4}{*}{$\begin{array}{l}\text { Condition- } \\
\text { Event }\end{array}$} & $\begin{array}{l}\text { 1. Si ocurre una quemadura con un ácido concentrado, por ningún motivo se } \\
\text { recomienda lavar la zona comprometida con agua de manera directa. }\end{array}$ \\
\hline & $\begin{array}{l}\text { 'If a burn occurs with concentrated acid, it is not recommended to wash the burned area directly with } \\
\text { water for any reason.' }\end{array}$ \\
\hline & $\begin{array}{l}\text { 2. Cuando se enciende un artefacto eléctrico, miles y miles de cargas eléctricas fluyen } \\
\text { a través de todos sus cables internos. }\end{array}$ \\
\hline & $\begin{array}{l}\text { 3. Cuando se pone un vaso invertido sobre una vela, comienza un proceso en el que la } \\
\text { llama se irá extinguiendo hasta apagarse por completo. }\end{array}$ \\
\hline
\end{tabular}




\begin{tabular}{|c|l|}
\hline \multirow{5}{*}{$\begin{array}{c}\text { Concept } \\
\text { Specification }\end{array}$} & $\begin{array}{l}\text { 4. Si contienes la respiración, es común que el dióxido de carbono se comience a } \\
\text { acumular en tu sangre. }\end{array}$ \\
\cline { 2 - 3 } & $\begin{array}{l}\text { 5. Si disminuye la temperatura, se observa que los gases tienden a sufrir una } \\
\text { disminución considerable en su volumen. } \\
\text { entorno. Uno de los daños más importante se presenta en la contaminación severa del } \\
\text { agua. }\end{array}$ \\
\cline { 2 - 3 } & $\begin{array}{l}\text { 'It is well known that volcanic eruptions produce severe damage to the entire environment. One of the } \\
\text { most important damages is severe water contamination. }\end{array}$ \\
\cline { 2 - 3 } & $\begin{array}{l}\text { 2. Recientemente, la Organización Meteorológica Mundial ha clasificado a las nubes } \\
\text { en } 10 \text { grandes tipos. Entre estos tipos, los más conocidos popularmente corresponden } \\
\text { a los cirrus y los cúmulos. }\end{array}$ \\
\cline { 2 - 3 } $\begin{array}{l}\text { 3. Según los registros de la NASA, se han observado más de 60 satélites orbitando } \\
\text { Saturno. De todos ellos, el de mayor tamaño registrado hasta la fecha es el de Titán. }\end{array}$ \\
\cline { 2 - 3 } $\begin{array}{l}\text { 4. En la naturaleza existen dos grandes tipos de fuentes de energía: renovables y no } \\
\text { renovables. Las energías renovables corresponden a aquellas energías que se extraen } \\
\text { de fuentes naturales inagotables. }\end{array}$ \\
\cline { 2 - 2 } $\begin{array}{l}\text { 5. Según los registros más actuales de la NASA, Júpiter tiene más de } 60 \text { satélites. De } \\
\text { ellos, los cuatro más grandes y conocidos son Ío, Calisto, Ganímedes y Europa. }\end{array}$ \\
\hline
\end{tabular}

APPENDIX C. Description of coherence relations used in the self-paced reading experiment. 5

\begin{tabular}{|c|c|c|c|}
\hline $\begin{array}{l}\text { Type } \\
\text { relation }\end{array}$ & Definition & Formalization & Example \\
\hline Conjunction & $\begin{array}{l}\text { A coherence relation } \\
\text { is established when } \\
\text { two events share a } \\
\text { common contextual } \\
\text { situation. }\end{array}$ & $\mathrm{P}$ and $\mathrm{Q}$ & $\begin{array}{l}\text { In a play, the closing of the curtain } \\
\text { determines the end of an act. Nowadays, } \\
\text { it is common for dramatic works to be } \\
\text { structured in a single act. }\end{array}$ \\
\hline $\begin{array}{l}\text { Concept } \\
\text { Description }\end{array}$ & $\begin{array}{l}\text { A coherence relation } \\
\text { is established when } \\
\text { an event describes a } \\
\text { concept that is in } \\
\text { another event. }\end{array}$ & $\begin{array}{l}\mathrm{E}_{2} \text { describes } \mathrm{C} \\
\text { in } \mathrm{E}_{1}\end{array}$ & $\begin{array}{l}\text { The Coastal Range keeps the name } \\
\text { Nahuelbuta. From the Tolten River to } \\
\text { the south, it is commonly known as } \\
\text { Mahuidanche. }\end{array}$ \\
\hline $\begin{array}{l}\text { Claim- } \\
\text { Argument }\end{array}$ & $\begin{array}{l}\text { A coherence relation } \\
\text { is established when a } \\
\text { claim is supported by } \\
\text { an event, which is } \\
\text { used as evidence. }\end{array}$ & $\begin{array}{l}\mathrm{Q} \text { is supported } \\
\text { by } \mathrm{P}\end{array}$ & $\begin{array}{l}\text { Diego Portales was one of the most } \\
\text { important people of the 19th century } \\
\text { since his participation in politics was key } \\
\text { in the } 1820 \text { s and } 1830 \text { s events. }\end{array}$ \\
\hline $\begin{array}{l}\text { Event } \\
\text { Description }\end{array}$ & $\begin{array}{l}\text { A coherence relation } \\
\text { is established when } \\
\text { an event describes } \\
\text { another event. }\end{array}$ & $\mathrm{E}_{2}$ describes $\mathrm{E}_{1}$ & $\begin{array}{l}\text { During the Middle Ages, the area around } \\
\text { the Mediterranean Sea was divided into } \\
\text { three large zones: Christian Europe, the } \\
\text { Byzantine Empire, and the Muslim } \\
\text { Empire. The division is remembered for } \\
\text { the complex relations between these } \\
\text { cultures, with periods of tension and } \\
\text { others of exchange. }\end{array}$ \\
\hline Act-Purpose & $\begin{array}{l}\text { A coherence relation } \\
\text { is established when } \\
\text { one or more acts are } \\
\text { carried out to achieve } \\
\text { one or more } \\
\text { objectives. }\end{array}$ & $\begin{array}{l}\mathrm{Q} \text { is carried out } \\
\text { to } \mathrm{P}\end{array}$ & $\begin{array}{l}\text { Suspense points are used to represent a } \\
\text { moment of suspense, doubt, fear, or } \\
\text { hesitation during the telling of a story. }\end{array}$ \\
\hline $\begin{array}{l}\text { Condition- } \\
\text { Event }\end{array}$ & $\begin{array}{l}\text { A coherence relation } \\
\text { is established when }\end{array}$ & If $\mathrm{P}$, (non) $\mathrm{Q}$ & $\begin{array}{l}\text { If a burn occurs with concentrated acid, } \\
\text { it is not recommended to wash the }\end{array}$ \\
\hline
\end{tabular}




\begin{tabular}{|l|l|l|l|}
\hline & $\begin{array}{l}\text { one or more events } \\
\text { or states determine } \\
\text { the (non) occurrence } \\
\text { of other events. }\end{array}$ & $\begin{array}{l}\text { burned area directly with water for any } \\
\text { reason. }\end{array}$ \\
\hline $\begin{array}{l}\text { Concept } \\
\text { Specification }\end{array}$ & $\begin{array}{l}\text { A coherence relation } \\
\text { is established when } \\
\text { an event specifies a } \\
\text { concept that is in } \\
\text { another event. }\end{array}$ & $\begin{array}{l}\mathrm{E}_{2} \text { specifies C } \\
\text { in } \mathrm{E}_{1}\end{array}$ & $\begin{array}{l}\text { It is well known that volcanic eruptions } \\
\text { produce severe damage to the entire } \\
\text { environment. One of the most important } \\
\text { damages is severe water contamination. }\end{array}$ \\
\hline
\end{tabular}

\section{NOTES}

${ }^{1}$ Available in https://www.psychopy.org/

2 Available in https://diamas.cl

${ }^{3}$ With the purpose of clarifying how are the experimental items, the first item of each condition was translated to English.

${ }^{4}$ The same as in Appendix 1, the first item of each condition was translated to English.

${ }^{5} \mathrm{P}$ and $\mathrm{Q}$ correspond to the antecedent and consequent of a relational coherence relation, respectively. E corresponds to an event, while $\mathrm{C}$ is a concept within an additive relation (see Ibáñez et al., 2015). 